\title{
Analisis Tokoh dan Penokohan Dalam Novel Yang Berjudul Dia Adalah Kakak Ku Karya Tere Liye
}

\author{
La Ode Madina ${ }^{1 *}$, Frenny S. Pormes ${ }^{2}$ \\ Universitas Victory Sorong \\ ${ }^{1}$ laodemadinanoken@gmail.com
}

\begin{abstract}
Abstrak
Penelitian ini bertujuan untuk mendeskripsikan tokoh dan penokohan yang terdapat dalam novel "Aku Mencintaimu Shayuan" karya Es Pernyata. Teknik pengumpulan data yang dilakukan dalam Penelitian ini adalah teknik pustaka dengan menganalisis isi. Teknik analisis data yang digunakan dalam Penelitian ini adalah teknik model analisis mengalir, yang meliputi tiga komponen, yaitu (1) reduksi data, (2) penyajian data, dan (3) penarikan simpulan. Berdasarkan hasil penelitian dapat disimpulkan tokoh utama dalam novel "Dia Adalah Kakakku" karya Tere Liye adalah Laisa, sedangkan tokoh tambahan yaitu Mamak Lainuri, Dalimunte, Ikanuri, Wibisana, dan Yashinta. Tokoh utama yaitu Laisa memiliki watak penyimpan penderitaan sendiri, pengalah, galak, selalu melakukan yang terbaik untuk adik-adiknya, teladan yang baik, selalu menepati janji, tegas dan disiplin, pekerja keras, orang yang tegar, tidak pernah mengeluh, tidak mudah menyerah, penyayang dan pelindung keluarga serta rela berkorban. Sedangkan Tokoh tambahan terdiri dari : a) Mamak Lainuri memiliki watak selalu baik, kuat, pekerja keras, cinta keluarga dan bijaksana merawat anak-anaknya. b) Dalimunte memiliki watak yaitu pintar, rajin membantu, pengertian, mudah sedih dan menangis, keras kepala, tidak mudah mengambil keputusan. c) Wibisana memiliki watak sebagai berikut : bijaksana, nakal dan jahil, suka mencuri , keras kepala. d) Ikanuri memiliki watak sebagai berikut : nakal dan jahil, suka menipu, suka melawan kakaknya, keras kepala, sulit meyembunyikan perasaannya. e) Yashinta memiliki watak sebagai berikut : memiliki rasa ingin tahu yang besar dan tidak sabar, suka merajuk, perhatian, mencintai alam, pintar dan cerdas serta penyayang keluarga.
\end{abstract}

Kata Kunci : Novel, Tokoh, dan Penokohan

\section{Character Analysis and Affirmation in a Novel Entitled Dia Adalah Kakak Ku by Tere Liye}

\begin{abstract}
This study aims to describe the characters and characterizations contained in the novel "I Love You Shayuan" by Es Pernyata. The data collection technique used in this study is a library technique by analyzing the content. The data analysis technique used in this study is a flow analysis model technique, which includes three components, namely (1) data reduction, (2) data presentation, and (3) drawing conclusions. Based on the results of the study, it can be concluded that the main character in Tere Liye's novel "Dia Is My Brother" is Laisa, while the additional characters are Mamak Lainuri, Dalimunte, Ikanuri, Wibisana, and Yashinta. The main character, Laisa, has a character that saves her own suffering, is submissive, fierce, always does the best for her younger siblings, is a good example, always keeps her promises, is firm and disciplined, hardworking, tough person, never complains, doesn't give up easily, loving and protective family and willing to sacrifice. While the additional characters consist of: a) Mamak Lainuri has a good character, is strong, hardworking, loves her family and is wise in taking care of her children. b) Dalimunte has a character that is smart, diligent to help, understanding, easy to be sad and cry, stubborn, not easy to make decisions. c) Wibisana has the following characteristics: wise, naughty and ignorant, likes to steal, stubborn. d) Ikanuri have the following characteristics: mischievous and ignorant, likes to cheat, likes to fight his brother, stubborn, hard to hide his feelings. e) Yashinta has the following characteristics: has a great curiosity and is impatient, likes to sulk, cares, loves nature, is smart and intelligent and loves family.
\end{abstract}

Keywords: Novels, Characters, and Characterizations 


\section{PENDAhuluan}

Sebuah novel menceritakan tentang kehidupan manusia dalam berinteraksi dengan lingkungan dan sesamanya. Novel dibangun melalui berbagai unsur, dua diantaranya adalah tokoh dan penokohan. Tokoh adalah individu rekaan yang mengalami peristiwa atau berkelakuan di dalam berbagai peristiwa cerita. sedangkan penokohan adalah cara pengarang menggambarkan atau melukiskan tokoh dalam cerita yang ditulisnya.

Menurut Nurgiyantoro (1994:166), penokohan menunjuk pada penempatan tokohtokoh tertentu dengan watak tertentu dalam sebuah cerita. Perilaku para tokoh dapat diatur melalui tindak-tanduk, ucapan, kebiasaan, dan sebagainya.

Satu di antara novel yang menarik untuk dideskripsikan tokoh dan penokohannya yaitu novel Dia Adalah Kakakku karya tere liye yang selanjutnya oleh penulis disingkat menjadi DAK. Penelitian ini dimaksudkan untuk meneliti secara mendetail Bagaimanakah Peran Tokoh dan watak Tokoh dalam novel "Dia Adalah Kakak Ku karya Tere Liye"

\section{METODE}

\subsection{Jenis Penelitian}

Penelitian ini menggunakan pendekatan kualitatif. Yang didasarkan pada data yang ada, mengikuti desain penelitian yang flleksibel sesuai dengan konteks.

\subsection{Teknik Pengumpulan Data}

Teknik pengumpulan data yang dilakukan dalam penelitian ini adalah teknik pustaka dengan menganalisis isi. Adapun langkahlangkah pengumpulan data yaitu (1) Membaca secara saksama dan berulang-ulang novel. (2) Mencatat setiap kata dan kalimat yang menggambarkan adanya gambaran tokoh dan penokohan.

\subsection{Teknik Analisis Data}

Teknik analisis data yang digunakan dalam penelitian ini adalah teknik model analisis mengalir, yang meliputi tiga komponen, yaitu (1) reduksi data, (2) penyajian data, (3) penarikan kesimpulan.

\section{HASIL DAN PEMBAHASAN}

\subsection{Hasil Penelitian}

Hasil penelitian tokoh dan penokohan dalam novel berjudul "Dia Adalah Kakak Ku" karya Tere Liye" adalah sebagai berikut.

\begin{tabular}{|c|ll|}
\hline \multirow{4}{*}{ Tokoh Utama } & \multicolumn{2}{|l|}{ Tokoh Tambahan } \\
\hline \multirow{4}{*}{ Laisa } & 1. & Dalimunte \\
\cline { 2 - 2 } & 2. & Wibisana \\
\cline { 2 - 2 } & 3. & Ikanuri \\
\cline { 2 - 2 } & 4. & Yashinta \\
\cline { 2 - 2 } & 5. & Mamak Lainuri \\
\hline
\end{tabular}

\begin{tabular}{|c|c|}
\hline Tokoh & Watak tokoh \\
\hline Laisa & $\begin{array}{l}\text { 1) Seorang pribadi yang } \\
\text { menyimpan penderitaan } \\
\text { sendiri } \\
\text { 2) Seorang pribadi yang } \\
\text { selalu mengalah } \\
\text { 3) Seorang pribadi yang } \\
\text { galak } \\
\text { 4) Seorang pribadi yang } \\
\text { selalu melakukan yang } \\
\text { terbaik Seorang pribadi } \\
\text { yang dijadikan adik- } \\
\text { adiknya, Teladan yang } \\
\text { baik } \\
\text { 5) Seorang pribadi yang } \\
\text { selalu menepati janji } \\
\text { 6) Seorang pribadi yang } \\
\text { Tegas dan disiplin } \\
\text { 7) Seorang pribadi yang } \\
\text { selalu bekerja keras } \\
\text { 8) Seorang pribadi yang tegar } \\
\text { 9) Seorang pribadi yang tidak } \\
\text { pernah mengeluh } \\
\text { 10) Seorang pribadi yang } \\
\text { tidak Mudah Menyerah } \\
\text { 11) Seorang pribadi yang } \\
\text { penyayang dan pelindung } \\
\text { keluarga } \\
\text { 12) Seorang pribadi yang } \\
\text { selalu bersyukur dan } \\
\text { ikhlas } \\
\text { 13) Seorang pribadi yang rela } \\
\text { berkorban. }\end{array}$ \\
\hline Mamak Lainuri & $\begin{array}{l}\text { 1) } \begin{array}{l}\text { Seorang pribadi yang baik } \\
\text { hati }\end{array} \\
\text { 2) } \begin{array}{l}\text { Seorang pribadi yang kuat } \\
\text { (tegar) }\end{array} \\
\text { 3) } \begin{array}{l}\text { Seorang pribadi yang } \\
\text { selalu bekerja keras }\end{array} \\
\text { t) Seorang pribadi yang } \\
\text { sangat mencintai } \\
\text { keluarganya }\end{array}$ \\
\hline Dalimunte & $\begin{array}{ll}\text { 1) Seorang pribadi yang } \\
\text { pintar } \\
\text { 2) Seorang pribadi yang } \\
\text { rajin membantu } \\
\text { 3) Seorang pribadi yang } \\
\text { pengertian }\end{array}$ \\
\hline
\end{tabular}




\begin{tabular}{|c|c|}
\hline & $\begin{array}{l}\text { 4) Seorang pribadi yang } \\
\text { mudah sedih dan } \\
\text { menangis } \\
\text { 5) Seorang pribadi yang } \\
\text { keras kepala } \\
\text { 6) Seorang pribadi yang } \\
\text { Tidak mudah mengambil } \\
\text { keputusana }\end{array}$ \\
\hline Wibisana & \begin{tabular}{ll} 
1) & \multicolumn{1}{c}{ Keras kepala } \\
2) & Suka mencuri \\
3) & Nakal dan jahil \\
\end{tabular} \\
\hline Ikanuri & $\begin{array}{l}\text { 1) Seorang pribadi yang } \\
\text { Nakal dan jahil } \\
\text { 2) Seorang pribadi yang Suka } \\
\text { menipu } \\
\text { 3) Seorang pribadi yang Suka } \\
\text { melawan kakaknya } \\
\text { 4) Seorang pribadi yang } \\
\text { Keras kepala } \\
\text { 5) } \begin{array}{l}\text { Seorang pribadi yang Sulit } \\
\text { meyembunyikan } \\
\text { perasaannya }\end{array}\end{array}$ \\
\hline Yashinta & $\begin{array}{l}\text { 1) Seorang pribadi yang } \\
\text { Memiliki rasa ingin tahu } \\
\text { yang besar dan tidak sabar } \\
\text { 2) Seorang pribadi yang Suka } \\
\text { merajuk } \\
\text { 3) Seorang pribadi yang } \\
\text { Perhatian } \\
\text { 4) Seorang pribadi yang } \\
\text { Mencintai alam } \\
\text { 5) Seorang pribadi yang } \\
\text { Pintar dan cerdas } \\
\text { 6) Seorang pribadi yang } \\
\text { Penyavang keluarga }\end{array}$ \\
\hline
\end{tabular}

\subsection{Pembahasan}

Pada bagian ini diuraikan pembahasan tentang tokoh dan penokohan dalam novel "Dia Adalah Kakak Ku karya Tere Liye" Nurgiyantoro (1994:166), berpendapat Tokoh adalah individu rekaan yang mengalami peristiwa atau berkelakuan di dalam berbagai peristiwa cerita. sedangkan penokohan adalah cara pengarang menggambarkan atau melukiskan tokoh dalam cerita yang ditulisnya

Tokoh dibagi menjadi dua bagian, yaitu tokoh utama dan tokoh tambahan.

\section{a. Tokoh Utama}

Tokoh utama dalam novel "Dia Adalah Kakakku" karya Tere liye adalah Laisa, karena tokoh Laisa merupakan tokoh yang paling banyak diceritakan dan paling banyak menimbulkan konflik.

\section{b. Tokoh Tambahan}

Tokoh tambahan adalah tokoh yang mendukung tokoh utama. Peneliti membatasi analisis tokoh tambahan yang paling banyak berhubungan dengan tokoh utama, yaitu Mamak Lainuri, Dalimunthe, Ikanuri, Wibisana, dan Yashinta.

\section{Penokohan}

Analisis penokohan tokoh utama dalam novel" Dia Adalah kakak ku" Tokoh utama dalam cerita ini adalah

\section{a. Laisa.}

Ia dikenal dengan tokoh yang berwatak sebagai berikut:

\section{1) Penyimpan penderitaan sendiri}

Hal ini dilihat dari kutipan di bawah ini :

Kak Laisa selalu sigap dan disiplin menghadapi rutinitasnya. Jadi mana mungkin Kak Laisa sakit? Tapi pesan dari mamak Lainuri pasti seius." (Dia adalah Kakakku, 2018: 74)

"Kak Laisa yang tidak pernah menangis di depan adik-adiknya. Tidak pernah. Sesakit apa pun, sesesak apa pun rasanya. Kak Laisa akan selalu berusaha terlihat semua baik-baik saja." (Dia adalah Kakakku, 2018: 188)

\section{2) Pengalah}

Hal ini ditunjukkan pada kutipan beriku: Ia tidak tahu kalau sebenarnya Kak Laisa yang memutuskan untuk mengalah tidak sekolah agar adik-adiknya bisa sekolah." (Dia adalah Kakakku, 2018: 78-79)

\section{3) Selalu menepati janji}

Hal ini ditunjukkan pada kutipan di bawah ini: Kak Laisa tidak pernah mengingkari janjijanjinya, demi kita adik-adiknya." (Dia adalah kakakku, 2018 :138)

Terhenti. Gerakan tubuh harimau terbesar itu terhenti.

"TIDAK! PUYANG TIDAK BOLEH MEMAKAN MEREKA!" (Dia adalah kakakku, 2018 : 143)

“..... Untuk kak Laisa yang selalu menepati janji, tidak pernah datang terlambat buat kami" (Dia adalah kakakku, 2018: 263)

\section{4) Orang yang tegar}

Hal itu dapat dilihat pada kutipan berikut :

Laisa meremas pahanya kencang-kencang. Berusaha mengalihkan rasa sakit di hati ke rasa sakit di tubuhnya. (Dia adalah Kakakku, 2018 : 119)

\section{5) Rela berkorban}

Hal tersebut dilihat pada kutipan berikut:

"Jika harus ada yang kecewa dan malu, itu adalah dirinya bukan adik-adiknya. Bagi Laisa, 
sepak Babak pergi, hidupnya amat sederhana. Adik-adiknya berhak atas masa depan yang lebih baik dibandingkan dirinya." (Dia adalah kakakku, 2018 : 100-101)

\section{b. Dalimute}

Ia dikenal dengan tokoh yang berwatak sebagai berikut :

1) pintar.

Hal ini dilihat dari kutipan di bawah ini:

"Lulus dari institute teknologi ternama itu, Dalimunte melanjutkan sekolah di Universitas terbaik di Amerika. Mendapatkan beasiswa selama tiga tahun untuk menyelesaiakn jenjang doctor ilmu fisikanya".(Dia adalah kakakku, 2018: 225)

\section{2) Mudah sedih dan menangis} ini:

Hal ini ditunjukkan dalam kutipan di bawah

“Kenapa kak Lais tidak bilang?” Dalimunte menangis, tersendat. Jemari tangannya gementar mengusap bibir perempuan umur empat puluh tahun yang terbating lemah diatas ranjang. Ada berkas darah di sana. Keluar bersama dahak.(Dia adalah Kakakku, 2018 : 175)

\section{3) Keras kepala} ini:

Hal ini ditunjukkan pada kutipan di bawah

"Jangan paksa Dali menikah. Jangan paksa Dali" "Tidak ada yang memaksamu, Dali! TIDAK ADA! tapi jika kau keras kepala, kau akan kehilangan Cie Hui selamanya.... kau akan membuat semuanya binasa dengan segala kekerasan dan omong kosong melintas itu.'Kak Laisa berkata serak. (Dia Adalah Kakakku, 2018: 236)

\section{4) Tidak mudah mengambil keputusana} ini :

Hal ini ditunjukkan dalam kutipan di bawah

"Aku sudah bilang, Kak Laisa. Aku sudah bilang ke Dalimunte. Tapi, tapi ia tidak bisa mengambil keputusan." Gadis manis berkerudung lembut itu menangis di pangkuan Kak Laisa. (Dia Adalah Kakakku, 2018: 233)

Dalimunte tetap tak kuasa mengambil keputusan. Ia terlalu menghargai Kak Laisa. (Dia Adalah Kakakku, 2018: 236)

\section{c. Wibisana.}

Ia dikenal dengan tokoh yang berwatak sebagai berikut:

\section{1) Bijaksana}

Hal ini ditunjukkan pada kutipan di bawah ini:

"Wibisana menepuk-nepuk bahu Ikanuri. Tersenyum. Berbisik, "Tidak akan terjadi apaapa, Ikanuri. Kita akan tiba tepat waktu. Berdoalah, Kakak Laisa akan baik-baik saja.(Dia Adalah Kakakku,2018: 105)

"Wibisana menelan ludah. Menepuk lembut bahu Ikanuri.

"Kita tidak akan terlambat, Ikanuri, tidak akan.”.(Dia Adalah Kakakku,2018: 138)

\section{2) Jahil} ini:

Hal ini ditunjukkan dalam kutipan di bawah

"Biasa penemu. Paling juga bawa peta harta karun.'Ikanuri dan Wibisana nyengir. Tertawa mengolok. Mereka berdua selama ini suka jahil merusak kertas-kertas atau apa saja yang dikerjakan Dalimunte. (Dia Adalah Kakakku, 2018:85)

"Biasa penemu. Paling juga bawa peta harta karun.'Ikanuri dan Wibisana nyengir. Tertawa mengolok. Mereka berdua selama ini suka jahil merusak kertas-kertas atau apa saja yang dikerjakan Dalimunte. (Dia Adalah Kakakku, 2018:85)

\section{3) Keras kepala}

Hal ini ditunjukkan dalam kutipan di bawah ini:

"Biasa penemu. Paling juga bawa peta harta karun."Ikanuri dan Wibisana nyengir. Tertawa mengolok. Mereka berdua selama ini suka jahil merusak kertas-kertas atau apa saja yang dikerjakan Dalimunte. (Dia Adalah Kakakku, 2018:85)

"Kalau dulu kita yang mengajak Yash melihat anak harimau di Gunung Kendeng, pasti tadi juga disebut-sebut." Ikanuri, nyengir, tertawa kecilmelihat Yashinta yang masih memeluk Kak Laisa. . (Dia Adalah Kakakku, 2018:264)

\section{4) Suka menipu}

Hal ini ditunjukkan pada kutipan di bawah ini:

"Ini juga gaya favorit Ikanuri waktu kecil dulu, saat menipu guru di kelas, saat ketahuan membolos. Atau ketahuan mencuri uang di kelpeh-dompet-mamak Lainuri. Sok bego belagak tidak mengerti." (Dia adalah Kakakku, $2018: 39$ )

\section{5) Suka melawan kakaknya} ini

Hal ini ditunjukkan dalam kutipan di bawah 
"Omelan mamak Lainuri mala mini hanya mempan seminggu. Ikanuri dan Wibisana memang rajin sekolah, sok rajin belajar, shalat di surau, lancer ngajinya, tidak banyak bertinhkah dan patuh dengan kakak Laisa selamaseminggu terakhir. Namun, lepas satu pekan, tabiat lama mereka kembali lagi. Lebih parah malah. (Dia Adalah Kakakku, 2018:109)

\section{6) Keras kepala} ini.

Hal ini ditunjukkan dalam kutipan di bawah

"Meski keras kepala, selalu membantah, kedua sigul kecil itu membuat masa remaja yang sulit dan penuh kerja keras menjadi berwarna dan berisik sepanjang. (Dia adalah Kakaku, 2018 : 273)

\section{d. Yashinta.}

Ia dikenal dengan tokoh yang berwatak sebagai berikut:

1) Memiliki rasa ingin tahu yang besar dan tidak sabar

Hal ini nampak pada kutipan di bawah ini:

"Kakak bawa apa, sih? Yashinta bertanya, melihat kertas-kertas yang dipegang Delimunte. (Dia adalah Kakakku, 2018:85)

"Masih jauh! Dan kau jangan sampai terpeleset, YASH!” (Dia adalah Kakakku, 2018 : 43)

"Masih jauh, Kak?" gadis yang berumur tujuh tahun bertanya lagi sambil melepas daun yang tersangkut di rambut.

Tidak ada Jawaban.

"Masih jauh, Kak? Lima menit?Sepuluh menit? (Dia adalah Kakakku, 2018 : 45)

\section{2) Suka merajuk} ini.

Hal ini ditunjukkan dalam kutipan di bawah

"Biarin!Pokoknya lucu!" Yashinta cemberut, tidak memperdulikan kedua kakaknya. (Dia adalah Kakakku, 2018 : 47)

"Kak Laisa bilang aku bisa sekolah di mana saja.aku tidak mau sekolah di sini. TIDAK MAU!" Yashinta merajuk. Matanya melotot. (Dia adalah Kakakku, 2018 : 215)

"Yas seharusnya tidak marah.Yash seharusnya terbiasa."... (Dia adalah Kakakku, 2018 : 217)

\section{3) Perhatian} ini.

Hal ini ditunjukkan dalam kutipan di bawah

"Nanti Yashita kasih minyak urut.”Yashita berbisik pelan, mengambil bunga rumput di dahinya. (Dia adalah Kakakku, 2018 : 69-70)

\section{4) Mencintai alam}

Hal ini ditunjukkan dalam kutipan di bawah ini.

"Yashinta nama gadis itu. Team leader kelompok penelitian kecil butung dan mamalia endemic. Selain menjadi peneliti dari lembaga penelitian dan konservasi nasional di Bogor, ia juga merangkap koresponden foto majalah Nasional Geographic." (Dia adalah Kakakku, $2018: 32-33$ )

\section{BAB V PENUTUP}

\section{A. Simpulan}

Berdasarkan hasil penelitian, maka dapat disimpulkan tokoh utama dalam novel "Dia Adalah Kakakku" karya Tere Liye adalah Laisa, sedangkan tokoh tambahan yaitu Mamak Lainuri, Dalimunte, Ikanuri, Wibisana, dan Yashinta.

Tokoh utama yaitu Laisa memiliki watak penyimpan penderitaan sendiri, pengalah, galak, selalu melakukan yang terbaik untuk adikadiknya, teladan yang baik, selalu menepati janji, tegas dan disiplin, pekerja keras, orang yang tegar, tidak pernah mengeluh, tidak mudah menyerah, penyayang dan pelindung keluarga serta rela berkorban. Sedangkan Tokoh tambahan terdiri dari : a) Mamak Lainuri memiliki watak selalu baik, kuat, pekerja keras, cinta keluarga dan bijaksana merawat anakanaknya. b) Dalimunte memiliki watak yaitu pintar, rajin membantu, pengertian, mudah sedih dan menangis, keras kepala, tidak mudah mengambil keputusan. c) Wibisana memiliki watak sebagai berikut : bijaksana, nakal dan jahil, suka mencuri , keras kepala. d) Ikanuri memiliki watak sebagai berikut : nakal dan jahil, suka menipu, suka melawan kakaknya, keras kepala, sulit meyembunyikan perasaannya. e) Yashinta memiliki watak sebagai berikut : memiliki rasa ingin tahu yang besar dan tidak sabar, suka merajuk, perhatian, mencintai alam, pintar dan cerdas serta penyayang keluarga.

\section{DAFTAR PUSTAKA}

[1] Arikunto, Suharismi. 1998. Proseder Penelitian. Jakarta: Rineka Cipta.

[2] Guntur, Henry Tarigan, 2011. Dasar-dasar Psikosastra. Angkasa Bandung : Bandung

[3] Liye, Tere, 2018. Dia Adalah Kakak Ku. Republika Penerbit : Jakarta

[4] Moleong, Lexi J. 2008. Metode Penelitian Kualitatif. Bandung: Remaja Rosda Karya. 
[5] Muhardi, dan Hasanuddin WS. 1992. Prosedur Analisis Fiksi. Padang : IKIP Padang.

[6] Nurgiyantoro, Burhan. 1994. Penilaian dalam Pengajaran Bahasa dan Sastra. BPFE Yogyakarta :Yogyakarta

[7] Nurgiyantoro, Burhan. 2010. Teori Pengkajian Fiksi. Yogyakarta: Gajah Mada

[8] Ratna, Nyoman Kutha. 2004. Teori, Metode, dan Teknik Penelitian Sastra.

[9] Yogyakarta: Pustaka Pelajar.

[10] Suyanto, Edi. 2012. Perilaku Tokoh Dalam Cerpen indonesia. Bandar lampung: Universitas Lampung. 183 hlm. 144 Jurnal Ilmiah Mahasiswa Jurusan PBSI Vol. 1 No. 4; Oktober 2016:144-153

[11] Ucha Riani, dkk. 2016. Analisis Tokoh Dan Penokohan Dalam Novel Sepatu Dahlan Karya Khrisna Pabichara. Jurnal Ilmiah Mahasiswa Jurusan PBSI Vol. 1 No. 4; Oktober 2016:144153

[12] Waslam. 2017. Analisis Tokoh Dan Penokohan Novel Jantan Karya Edijushanan. Jurnal. Forum Ilmiah Volume 14 Nomor 1, Januari 2017 